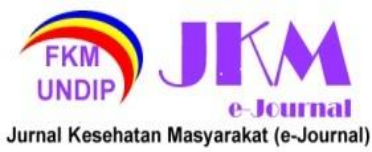

\author{
JURNAL KESEHATAN MASYARAKAT (e-Journal) \\ Volume 10, Nomor 1, Januari 2022 \\ ISSN: 2715-5617 / e-ISSN: 2356-3346 \\ http://ejournal3.undip.ac.id/index.php/jkm
}

\title{
PENERAPAN PROKES COVID-19 PADA RUANG PUBLIK DI JAWA TENGAH
}

\author{
Arif Sofianto $^{1^{*}}$, Mursid Zuhri' ${ }^{1}$, Lita Febrian' ${ }^{1}$, Okki Chandra Ambarwati ${ }^{1}$ \\ ${ }^{1}$ Badan Perencanaan Pembangunan, Penelitian dan Pengembangan Daerah Provinsi Jawa Tengah \\ Jl. Pamuda No. 127-133 Semarang, Jawa Tengah,Telp. (024) 3515591. Fax. (024) 3546802 \\ Corresponding author:01arifsofianto@gmail.com
}

\begin{abstract}
Covid-19 cases in Indonesia tend to increase, and several studies show that there is still a lack of public awareness on implementing health protocols. Public spaces have a greater potential for transmission than private spaces, so it is important to ensure the implementation of health protocols. The purpose of this study was to determine the potential for community behavior on implementing health protocols in public spaces, as well as how to improve efforts that need to be made. This type of research is descriptive with a mixed method quantitative and qualitative, and its applied research. This research was conducted using a survey technique involving 2,894 respondents spread throughout Central Java. The sample is probability sampling, determined by the technique of multistage random sampling and cluster random sampling. The instrument of this research is a semi-closed questionnaire which is given through google form media. The analysis in this study uses descriptive statistical techniques, as well as qualitative analysis of simultaneous models. This study concludes that public areas must be watched out for because they have the potential to create a fairly high level of the crowd, but the implementation of the covid-19 health protocols has not been optimal, especially tourist and entertainment places, public transportation, and traditional markets. Several places with high potential for visits, such as workplaces, places of worship, culinary places, and socio-religious celebrations/rituals, also need to improve the implementation of health protocols.
\end{abstract}

Keywords: covid-19, pandemic, public space, health protocol, Central Java

\section{PENDAHULUAN}

Saat ini pandemi Covid-19 telah menyebar ke berbagai negara di seluruh dunia. Pemerintah pusat maupun daerah melakukan berbagai upaya menekan angka penyebaran Covid19 dengan menghimbau masyarakat agar membatasi kerumunan dan menerapkan protokol kesehatan (prokes). Pemerintah juga telah menghimbau gerakan "5 M" yaitu menggunakan masker di keluar rumah, mencuci tangan dengan sabun, menjaga jarak, mengurangi bepergian, dan menghindari kerumunan. Pemerintah Provinsi Jawa Tengah mengeluarkan gerakan "Jogo Tonggo" melalui Instruksi Gubernur Jateng No. 1/2020 tanggal 22 April 2020 tentang Pembentukan "Satgas Jogo Tonggo". Prinsip "Jogo Tonggo" adalah gerakan tersinergi dari unsur kesehatan, ekonomi sosial, dan keamanan.

Survei BPS Jawa Tengah menunjukkan tingkat ketaatan masyarakat terhadap prokes cukup tinggi, terutama pada orang berusia antara $20-50$ tahun. ${ }^{(1)}$ Sebanyak 8 dari 10 orang sering atau selalu menggunakan masker ketika keluar rumah, cuci tangan dan penggunaan handsanitizer menjadi kebiasaan baru, (81 persen sering dan 65,1 persen selalu), dan 68,4 persen responden menerapkan jaga jarak. ${ }^{(1)}$

Di sisi lain, peningkatan kasus Covid-19 di Jawa Tengah terus terjadi, dan masuk kelompok 3 besar se-Indonesia. Salah satu tantangan utama dalam penanggulangan Covid 19 adalah masih banyak masyarakat yang tidak patuh terhadap prokes. Sebagai contoh penelitian Kuntardjo et.al di pasar Kota Semarang, bahwa sebagian besar pedagang belum patuh untuk menjaga jarak, mencuci tangan serta memakai masker dengan benar. ${ }^{(2)}$

Penelitian Rani dan Safarinda menyebutkan bahwa Jogo Tonggo belum mengurangi secara signifikan kasus positif Covid 19. (3) Masyarakat kurang sadar bahaya Covid-19, serta banyak yang mengabaikan himbauan pemerintah, sehingga implementasi Jogo Tonggo belum maksimal. ${ }^{(4)}$ Kedisiplinan warga untuk membatasi beraktivitas keluar rumah masih kurang, sehingga penerapan physical distancing di Jawa Tengah belum optimal. ${ }^{(1)}$

Pesan penting dalam penanganan pencegahan penyebaran Covid-19 melalui Program Jogo Tonggo tidak bisa diimplementasikan dengan baik karena pelaksana di lapangan (tingkat RW) mengalami kebingungan dalam imlementasinya. ${ }^{(5)}$ Penelitian lain menunjukkan pelaksana kebijakan Jogo Tonggo di lapangan belum mengetahui dengan pasti apa yang menjadi hak, kewajiban, tugas dan fungsi yang dimiliki. ${ }^{(4)}$

Hasil penelitian Listyaningrum dan Philona menunjukkan banyak masyarakat tidak menggunakan masker dan tidak menjaga jarak di tempat umum. ${ }^{(6)}$ Dalam rangka penanganan Covid 19, telah dilakukan upaya sosialisasi dan edukasi, namun banyak masyarakat yang tidak mematuhi 


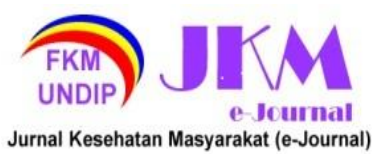

himbauan pemerintah. ${ }^{(7)}$ Sebaik apapun aturan serta setegas apapun aparat penegak hukum, jika tidak didukung oleh kesadaran masyarakat maka tidak akan tercapai penegakan hukum seperti yang diinginkan. ${ }^{(6)}$ Di DKI Jakarta, penyebab tingginya pelangggaran PSBB adalah karena rendahnya tingkat kepatuhan warga terhadap kebijakan PSBB. ${ }^{(8)}$ Penelitian lain juga menunjukkan sebagian masyarakat belum mampu menjaga kebersihan tangan dengan benar. ${ }^{(9)}$

Kurangnya kesadaran dari masyarakat menjadi kendala tersendiri dalam penegakan disiplin prokes. ${ }^{(6)}$ Warga masih beraktivitas ke luar rumah untuk tujuan rekreasi, bergerombol, berkumpul tanpa menggunakan masker ataupun menjaga jarak. ${ }^{(10)}$ Secara umum, sebagian masyarakat belum mematuhi PSBB atau peraturan prokes yang telah dibuat oleh pemerintah. ${ }^{(11)}$

Di sisi lain, muncul ketakutan pandemi ini akan merusak ekonomi dan sosial masyarakat. ${ }^{(12)}$ Masyarakat mengalami tekanan kehidupan sosial dan ekonomi, pendapatan menurun, lapangan kerja sulit, di sisi lain pengeluaran meningkat. ${ }^{(13)}$ Suryahadi et al. memperkirakan pandemi Covid-19 akan meningkatkan angka kemiskinan di Indonesia dimana lebih dari 1,3 juta orang akan menjadi miskin. ${ }^{(14)}$ Pandemi Covid-19 menyebabkan gelombang PHK, penurunan produksi, penurunan impor, peningkatan harga (inflasi), penurunan pariwisata, meningkatkan kemiskinan, dan pertumbuhan ekonomi tertekan mencapai level 2,5\%-0\%. ${ }^{(15)}$ Kemiskinan dan pengangguran makin meningkat karena banyak perusahaan melakukan PHK. ${ }^{(16)}$ Penelitian lain menemukan bahwa pandemi menyebabkan naiknya pengangguran, kekerasan dan krimininalitas, kepanikan dan stress (17). Sebanyak 15,6 persen pekerja terkena PHK, terutama sektor konstruksi, perdagangan, rumah makan dan jasa, transportasi, pergudangan dan komunikasi (18). Pembatasan juga menyebabkan kelesuan sektor perdagangan, terutama pasar tradisional yang sepi pembeli (19)(20). Di Jawa Tengah angka kemiskinan naik dari 10,58 persen atau 3.679.400 jiwa pada September 2019 menjadi 11,84 persen atau 4.119.930 pada September 2020. Pengangguran terbuka naik dari 4,44 di tahun 2019 menjadi 6,48 di tahun $2020^{(21)}$

Menyikapi kebijakan PSBB yang dikeluarkan pemerintah dalam mengatasi pandemi ini, perlu dilakukan kajian tentang implementasi prokes di ruang publik, mengingat ruang publik memiliki potensi penularan lebih besar dibanding ruang privat. Selama ini belum banyak dilakukan survey atau penelitian terkait implementasi prokes di ruang publik, dan potensi kerentanannya.

Berdasarkan penjelasan di atas, maka permasalahan yang perlu dikaji adalah bagaimana perilaku masyarakat terhadap penerapan prokes dalam kaitannnya dengan potensi penyebaran Covid-19 pada ruang publik di Jawa Tengah. Oleh sebab itu, diperlukan survei atau penelitian dalam rangka menggali lebih dalam mengenai perilaku masyarakat dalam penerapan prokes dan kaitannya dengan kunjungan ke ruang publik.

\section{METODE PENELITIAN}

Penelitian ini berjenis deskriptif dengan pendekatan campuran dan bersifat penelitian terapan. Teknik yang survey digunakan dengan populasi seluruh penduduk Jawa Tengah sebanyak 34.718.214 jiwa, dengan derajat kepercayaan 95\%, atau alpha 0,05, dan margin of error sampel sebesar 2\%. Besaran sampel berdasar rumus Slovin dengan minimal 2.500 responden yang tersebar di seluruh wilayah Jawa Tengah.

Metode pengambilan sampel dilakukan dengan probability sampling melalui 2 cara utama yaitu multistage random sampling dan cluster random sampling. Multistage dilakukan dengan menentukan sampel berdasarkan lokasi tempat tingal responden mulai dari tingkat kabupaten, kecamatan, desa/kelurahan sampai RW dan RT dilakukan secara berjenjang memperhatikan aspek kewilayahan baik kota, pinggiran kota, maupun desa. Pemilihan responden secara acak dilakukan melalui bantuan para ketua RT. Cluster sampling dilakukan untuk menjaring responden pada ruangruang publik berupa tempat ibadah, pasar tradisional, pasar modern, tempat kuliner, wisata dan hiburan, tempat kerja, fasilitas transportasi, fasilitas olahraga, dan acara hajatan/ritual sosial keagamaan. Pemilihan responden secara acak dilakukan melalui bantuan para pengelola tempattempat tersebut.

Variabel yang dibahas dalam penelitian ini adalah tingkat ketaatan penerapan prokes oleh masyarakat, serta tingkat kunjungan masyaraka ke ruang publik. Penelitian ini mengkaitkan tingkat kunjungan masyarakat ke ruang/tempat publik dan tingkat ketaatan terhadap prokes.

Instrumen yang digunakan dalam penelitian ini adalah kuesioner semi tertutup yang diberikan melalui media google form. Analisis dalam penelitian menggunakan teknik deskriptif statistik dengan mengukur rata-rata dan jumlah menggunakan teknik tabulasi silang atau cross tab, dan perbandingan. Selain itu digunakan analisis kualitatif berupa model interaktif sebagaimana dikembangkan oleh Miles dan Huberman, yaitu reduksi, penyajian data dan penarikan kesimpulan.

\section{HASIL DAN PEMBAHASAN PROFIL RESPONDEN}




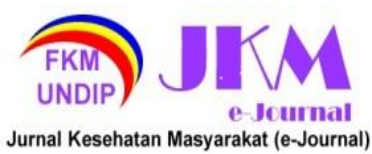

Penelitian ini melibatkan 2.894 responden di seluruh wilayah Jawa Tengah dengan mempertimbangan aspek keterwakilan wilayah Jawa Tengah, yaitu bagian barat, tengah, timur, pantura (pantai utara), serta pantai selatan. Responden terdistribusi di wilayah perkotaan, pinggiran, maupun pedesaan. Wilayah tersebut dipilah berdasarkan kawasan eks karesidenan di Jawa Tengah, yaitu Pati, Semarang, Surakarta, Kedu, Pekalongan, dan Banyumas.

Dari aspek demografis, responden dikelompokkan berdasarkan jenis kelamin, usia, pendidikan dan pekerjaan. Responden laki-laki sebanyak 1.660 orang $(57,36 \%)$, dan perempuan 1.234 orang $(42,64 \%)$. Usia responden beragam antara 9 - 75 tahun, dan didominasi usia produktif $30-60$ tahun.

Responden berasal dari berbagai kalangan pendidikan, yaitu tidak sekolah/tidak tamat SD (0.69\%), SD $(4,11 \%)$, SMP $(7,67 \%)$, SMA $(36,11 \%)$ Diploma (9, 05\%), D4/S1 $(33,86 \%)$ dan pasca sarjana $(8,50 \%)$. Berdasarkan pekerjaan responden terdiri dari kalangan pemerintahan (PNS/TNI/Polri, BUMN/BUMD) (27,92\%), pekerja swasta $(21,67 \%)$, pedagan $(8,67 \%)$, buruh dan sisanya pekerjaan dan kalangan lainnya.

\section{PENGETAHUAN ADAPTASI KEBIASAAN} BARU

Tabel 1. Pendapat responden mengenai era new normal

\begin{tabular}{llrr}
\hline No & \multicolumn{1}{c}{ Kategori pendapat } & jumlah & \% \\
\hline 1 & Perubahan perilaku (prokes) & 2612 & 90,27 \\
2 & Tatacara yang benar-benar baru & 135 & 4,66 \\
3 & Hidup normal biasa sebelum pandemic & 39 & 1,35 \\
4 & Tidak mengetahui & 44 & 1,52 \\
5 & Perubahan perilaku dan tata cara baru & 64 & 2,21 \\
\hline & Total & $\mathbf{2 . 8 9 4}$ & $\mathbf{1 0 0}$
\end{tabular}

Sumber: data primer 2020 (diolah)

\section{PENERAPAN PROKES}

Penelitian ini mengidentifikasi implementasi prokes Covid-19, melalui 10 indikator yaitu: 1) Menggunakan masker ketika keluar rumah; 2) Memakai sarung tangan dalam aktifitas di luar rumah; 3) Menggunakan hand sanitizer dan/atau disinfektan; 4) Mencuci tangan selama 20 detik dengan sabun; 5) Menghindari menyentuh wajah; 6) Menghindari berjabat tangan; 7) Menghindari pertemuan atau kerumunan; 8)
Pemahaman repsonden terkait adaptasi kebiasaan baru, memiliki beberapa variasi. Responden memiliki beberapa pendapat utama, yaitu: a) Perubahan perilaku untuk tetap menjalankan aktivitas normal dengan menerapkan prokes; b) Kehidupan dengan tatacara yang benar-benar baru; c) Hidup normal biasa seperti kehidupan sebelum terjadi pandemi Covid-19; dan d) Tidak mengetahui secara jelas, serta 5) kombinasi perubahan perilaku dengan tetap menjalankan aktivitas dan penerapan tatacara yang baru.

Mayoritas responden menyatakan bahwa adaptasi kebiasaan baru merupakan perubahan perilaku untuk tetap menjalankan aktivitas normal dengan menerapkan prokes. Dengan demikian, dari aspek kesadaran sudah cukup baik, dimana 90,26 persen menyatakan adanya perubahan perilaku sesuai prokes.

Pemahaman adaptasi kebiasaan baru berdasarkan jenis kelamin relatif tidak berbeda. Berdasarkan pendidikan, mereka yang memahami hidup seperti biasa seperti sebelum pandemi, atau tidak tahu lebih banyak pada jenjang pendidikan menengah ke bawah. Responden berusia di atas 60 tahun lebih banyak tidak tahu dibanding usia di bawahnya. Berdasarkan pekerjaannya, yang menjawab tidak tahu lebih banyak dari kelompok petani dan buruh.
Menghindari menyentuh benda di area publik; 9) Menghindari naik transpsortasi umum (termasuk transportasi online); dan 10) Menjaga jarak setidaknya 2 meter dari orang lain ketika keluar rumah. Terdapat 5 pilihan jawaban, yaitu tidak pernah, jarang, kadang-kadang, sering, dan selalu. Jika dikalkulasikan dalam bentuk persentase, maka perilaku responden dalam penerapan prokes berdasarkan indikator tersebut, sebagai berikut. 


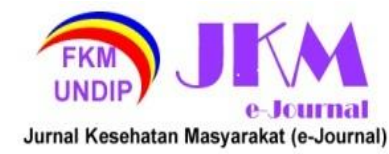

\section{JURNAL KESEHATAN MASYARAKAT (e-Journal) \\ Volume 10, Nomor 1, Januari 2022 \\ ISSN: 2715-5617 / e-ISSN: 2356-3346 \\ http://ejournal3.undip.ac.id/index.php/jkm}

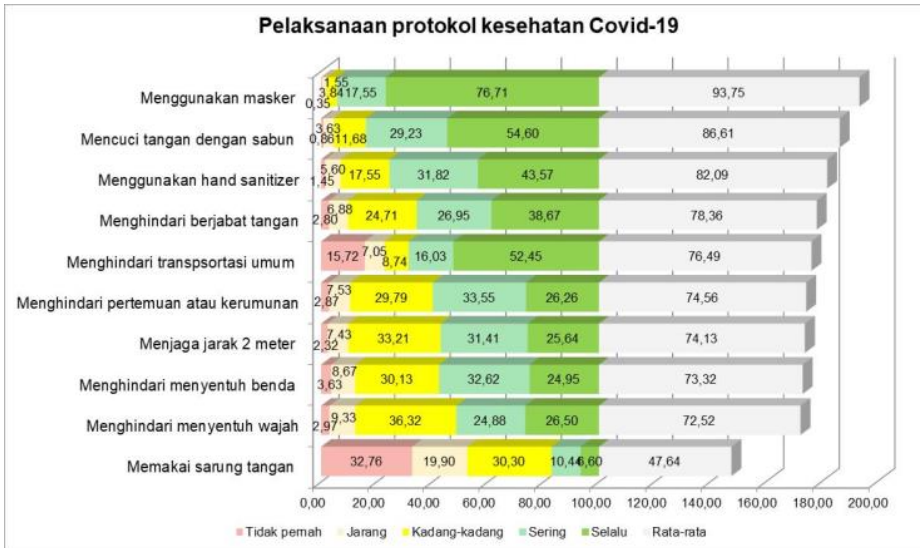

Gambar 1. Pelaksanaan prokes oleh responden

Prokes paling ditaati adalah menggunakan masker, dan menggunakan sarung tangan adalah yang paling tidak diperhatikan. Beberapa perilaku lain seperti menghindari menyentuh wajah, menghindari menyentuh benda, menjaga jarak, serta menghindari kerumuan juga masih perlu ditingkatkan. Transportasi umum menjadi dilema dimana sebagian orang tergantung dengan transportasi umum. Jika digeneralisasi menggunakan derajat persentase ketaatan, dimana yang tertinggi adalah selalu melaksanakan semua prokes $(100 \%)$, maka didapatkan hasil tingkat ketaatan/kepatuhan terhadap keseluruhan prokes Covid-19 sebesar 75,95\%. Jika dirinci skor setiap responden di dalam penerapan prokes responden terhadap keseluruhan indikator prokes tersebut dengan derajat skor terendah $0-20 \%$ (sangat rendah), dan tertinggi di atas $80 \%-100 \%$ (sangat tinggi), maka didapatkan hasil sebagai berikut.

Tabel 2. Derajat ketaatan responden terhadap prokes Covid-19

\begin{tabular}{lccccc}
\hline Skor & $\begin{array}{c}\text { Sangat rendah } \\
(\mathbf{0 - 2 0 \% )}\end{array}$ & $\begin{array}{c}\text { Rendah } \\
(\mathbf{2 1}-\mathbf{4 0 \% )}\end{array}$ & $\begin{array}{c}\text { Sedang } \\
(\mathbf{4 1 - 6 0 \% )}\end{array}$ & $\begin{array}{c}\text { Tinggi } \\
(\mathbf{6 1 - 8 0 \% )}\end{array}$ & $\begin{array}{c}\text { Sangat tinggi } \\
\mathbf{( 8 1 - 1 0 0 \% )}\end{array}$ \\
\hline Jumlah & 6 & 89 & 742 & 1518 & 539 \\
Persentase & 0,2 & 3,1 & 25,6 & 52,5 & 18,6 \\
\hline
\end{tabular}

Sumber: data primer 2020 (diolah)

Dari data di atas, secara umum tingkat ketaatan sudah cukup tinggi. Sebanyak 18,6 persen responden memiliki skor sangat tinggi atau selalu menaati prokes, dan 52,5 persen yang lainya tergolong tinggi atau sering menerapkan prokes. Sisanya sebagian kecil terbilang sedang dan rendah.

Aspek pemahaman, perilaku, dan sarana prasarana menjadi penyebab belum dilaksanakannya prokes dengan baik. Dari aspek pemahaman masyarakat sebagaimana diungkapkan responden ZUA bahwa hal tersebut terjadi karena kurangnya pemahaman terkait Covid-19, responden AD menyatakan bahwa masyarakat kurang peduli, dan merasa di lingkunganya aman. Pernyataan lainnya oleh FCK bahwa masyarakat belum terbiasa dengan prokes, sehingga sering lupa.

Dari aspek perilaku masyarakat, seorang responden (IP) menyatakan bahwa "saya sudah melaksanakan, tapi warga desa yang cuek dengan Covid-19". Responden (IN) juga menyatakan "misal di pasar, saya sudah memakai masker, cuci tangan, tapi penjual/pembeli lain malah belum melaksanakannya". Adapun pendapat responden lainnya (EP), "keluarga saya tegas dan taat melakukan prokes, bagaimana dengan yang lain? Padahal aktifitas sehari hari bersentuhan dengan mereka". Kemudian sebab lain penerapan prokes tidak optimal adalah karena belum tersedianya sarana dan prasarana yang memadai (IA).

\section{TEMPAT PUBLIK DAN PROKES}

Potensi kunjungan masyarakat ke tempat-tempat publik dapat menunjukkan seberapa besar potensi penularan pada tempat-tempat tersebut jika dikaitkan dengan tingkat ketaatan prokes. Tempat kerja menduduki peringkat tertinggi, kemudian disusul tempat ibadah dan pasar tradisional, tempat kuliner, dan acara hajatan/ritual sosial keagamaan. Acara pertemuan atau kerumunan besar merupakan area publik yang tidak banyak dikunjungi responden karena memang masih belum diperkenankan. Jika dikalkulasikan dalam persentase potensi kunjungan, dapat diperkirakan tingkat kunjungan ke area publik sebagai berikut: 


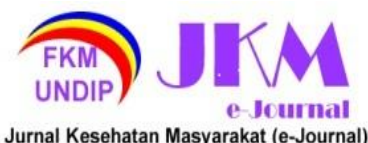

JURNAL KESEHATAN MASYARAKAT (e-Journal)
Volume 10, Nomor 1, Januari 2022

ISSN: 2715-5617 / e-ISSN: 2356-3346

http://ejournal3.undip.ac.id/index.php/jkm

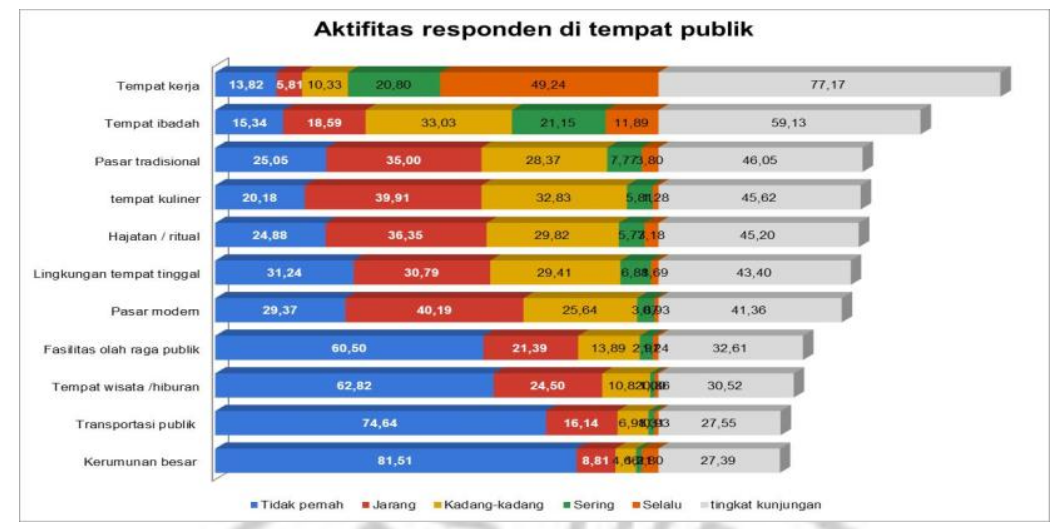

Gambar 2. Potensi kunjungan responden ke tempat publik

Potensi kunjungan ke tempat publik tersebut dapat dikaitkan dengan perilaku tertentu terhadap pelaksanaan prokes. Data pelaksanaan prokes oleh responden, dan kemungkinan mereka berkunjung ke tempat publik dapat dibandingkan dengan menggunakan skala persentase sebagai berikut.

\section{Kunjungan di tempat publik dan pelaksanaan protokol kesehatan oleh respoden \\ hajatan/ritual \\ tempat ibadah \\ tempat kuliner \\ pasar modern \\ tempat kerja \\ kerumunan besar \\ lingkungan tinggal \\ fasilitas olahraga \\ pasar tradisional \\ transportasi publik \\ tempat wisata/hiburan

\begin{tabular}{|c|c|c|c|c|c|}
\hline 79,60 & 75,83 & 72,77 & 73,35 & $\mathbf{8 3 , 2 4}$ & 76,96 \\
\hline 81,29 & 76,42 & 75,58 & 73,16 & $\mathbf{7 4 , 2 8}$ & 76,15 \\
\hline 78,90 & 76,81 & 74,00 & 70,75 & $\mathbf{7 6 , 1 6}$ & 75,32 \\
\hline 76,30 & 75,92 & 76,11 & 72,73 & $\mathbf{7 4 , 5 9}$ & 75,13 \\
\hline 75,93 & 72,90 & 74,62 & 73,18 & $\mathbf{7 7 , 7 6}$ & 74,88 \\
\hline 76,67 & 70,64 & 68,56 & 74,80 & $\mathbf{8 2 , 1 6}$ & 74,57 \\
\hline 79,77 & 76,61 & 76,61 & 68,48 & $\mathbf{7 0 , 0 0}$ & 74,29 \\
\hline 77,31 & 73,99 & 74,02 & 72,30 & $\mathbf{7 3 , 3 9}$ & 74,20 \\
\hline 79,09 & 76,44 & 75,33 & 69,37 & $\mathbf{6 8 , 7 5}$ & 73,79 \\
\hline 77,10 & 72,87 & 71,78 & 70,63 & $\mathbf{7 5 , 8 5}$ & 73,65 \\
\hline 77,98 & 73,26 & 71,25 & 70,00 & $\mathbf{6 9 , 7 6}$ & 72,45 \\
\hline
\end{tabular}

Gambar 3. Potensi kunjungan ke tempat publik dan pelaksanaan prokes

Responden yang selalu berkunjung ke acara hajatan atau ritual sosial keagamaan memiliki tingkat penerapan yang lebih baik dibanding mereka yang sering atau kadang-kadang berkunjung. Tingkat ketaatan terhadap prokes bagi mereka yang selalu atau sering berkunjung ke tempat ibadah tergolong cukup tinggi. Ketaatan lebih tinggi didapati pada orang yang kadangkadang, jarang, atau tidak pernah berkunjung ke tempat ibadah

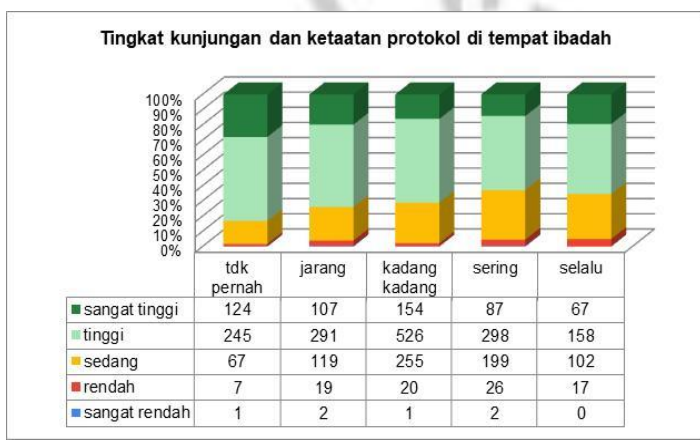

Gambar 4. Potensi kunjungan ke tempat ibadah dan pelaksanaan prokes

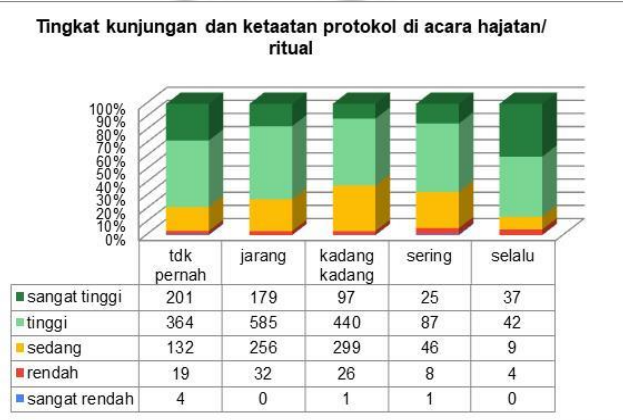

Gambar 5. Potensi kunjungan ke acara hajatan/ ritual social keagamaan dan pelaksanaan prokes 


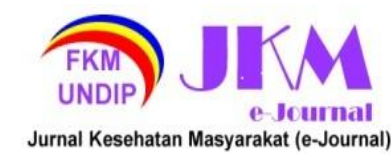

Responden yang selalu atau sering berkunjung ke pasar tradisional memiliki tingkat ketaatan dan penerapan prokes lebih rendah dibanding pengunjung pasar modern. Tingkat
JURNAL KESEHATAN MASYARAKAT (e-Journal)

Volume 10, Nomor 1, Januari 2022

ISSN: 2715-5617 / e-ISSN: 2356-3346

http://ejournal3.undip.ac.id/index.php/jkm

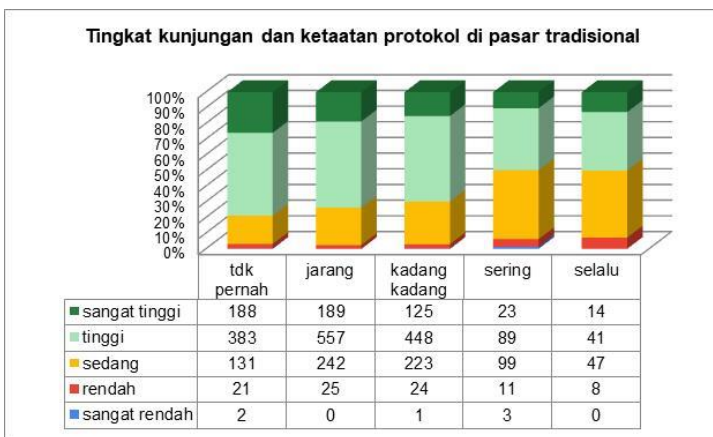

Gambar 6. Potensi kunjungan ke pasar tradisional dan pelaksanaan prokes

Tingkat ketaatan responden yang sering atau selalu berkunjung ke tempat wisata dan hiburan terbilang kurang dibanding yang jarang atau tidak pernah. Adapun bagi mereka yang

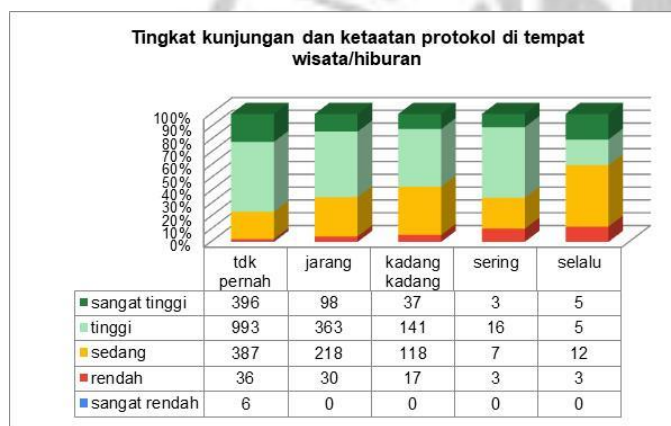

Gambar 8. Potensi kunjungan ke tempat wisata/hiburan dan pelaksanaan prokes

Sebagian besar responden yang sering atau selalu berkerumun di lingkungan tempat tinggal memiliki tingkat ketaatan yang agak ketaatan lebih tinggi terdapat pada mereka yang jarang atau tidak pernah berkunjung ke pasar tradisional maupun pasar modern.

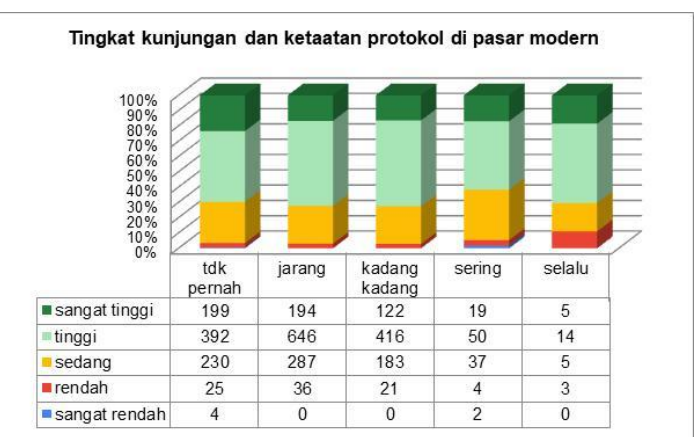

Gambar 7. Potensi kunjungan ke pasar modern dan pelaksanaan prokes

kadang-kadang berkunjung tingkat ketaatannya lebih baik. Sementara responden yang sering atau selalu berkunjung ke tempat kuliner makan memiliki tingkat ketaatan yang cukup baik.

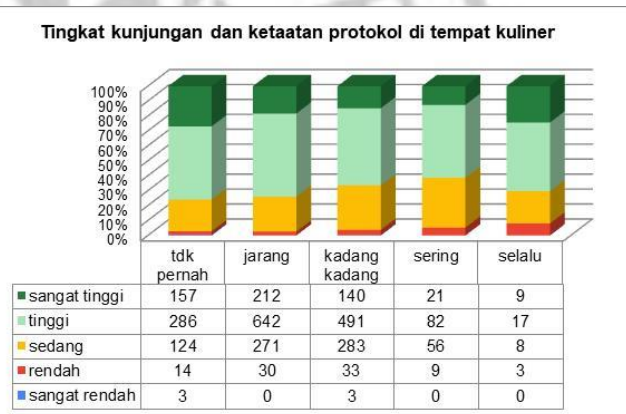

Gambar 9. Potensi kunjungan ke tempat kuliner dan pelaksanaan prokes

kurang. Responden yang selalu atau sering berkunjung ke acara kerumunan besar memiliki tingkat penerapan prokes yang cukup dan baik.

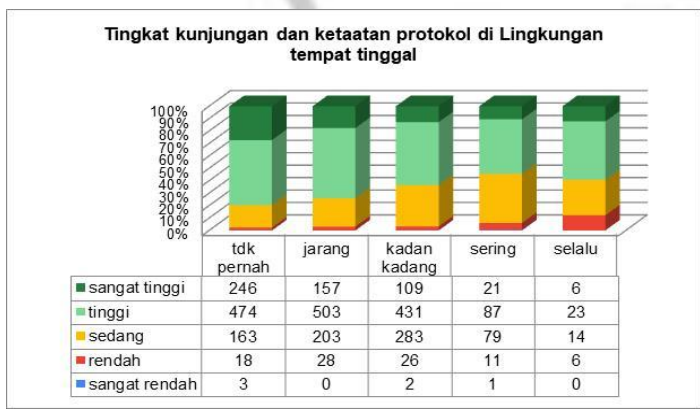

Gambar 10. Potensi berkerumun di lingkungan tinggal dan pelaksanaan prokes

Tingkat ketaatan mereka yang sering dan selalu menggunakan transportasi umum terbilang sedang, dan sebagian yang kadang-kadang atau

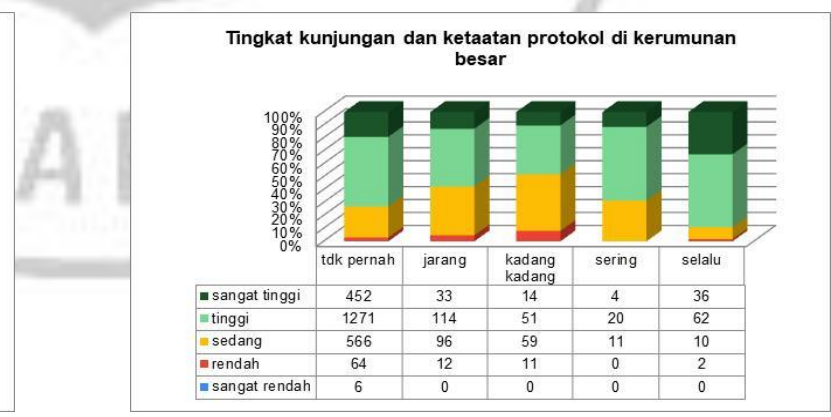

Gambar 11. Potensi berkerumun di acara besar/massal dan pelaksanaan prokes

tidak pernah menggunakan transportasi umum memiliki ketaatan yang lebih baik. Tingkat ketaatan responden yang sering dan selalu 


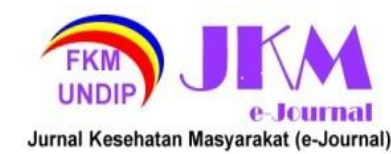

berkunjung ke fasilitas olahraga publik terbilang cukup, dan mereka yang jarang berkunjung ke

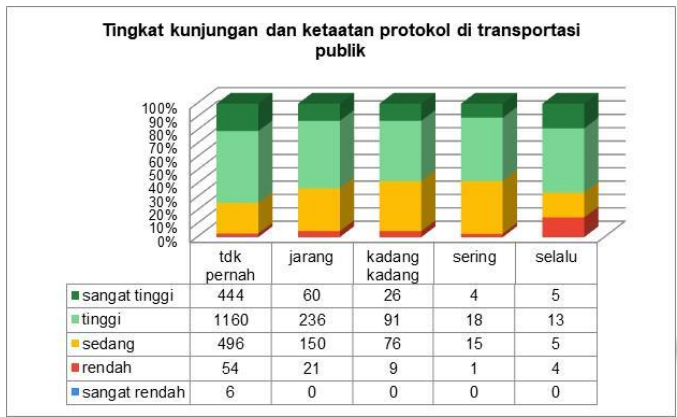

Gambar 12. Potensi kunjungan ke fasilitas transportasi publik dan pelaksanaan prokes

Ketaatan mereka yang selalu berkunjung ke tempat kerja terbilang cukup, meskipun masih ada sebagian respoden yang sering atau selalu berkunjung justru tingkat ketaatannya kurang.

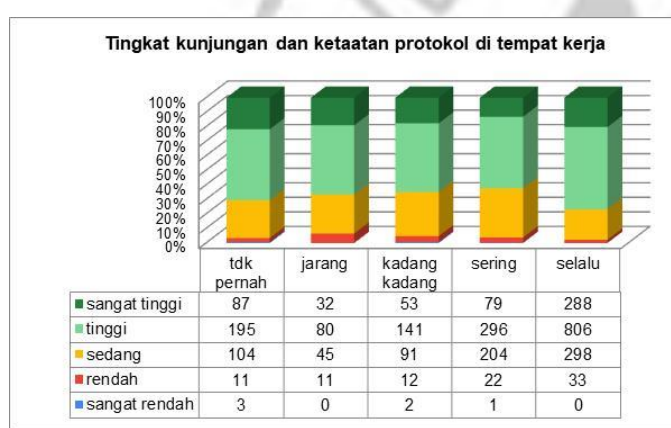

Gambar 14. Potensi kunjungan ke tempat kerja dan pelaksanaan prokes

Pada gambar 15 dapat dilihat perbandingan penerapan prokes dan potensi kunjungan ke masing-masing tempat publik. Ratarata potensi tingkat kunjungan ke semua tempat publik sebesar $43,27 \%$. Rata-rata potensi penerapan prokes di tempat publik sebesar $74,67 \%$. Tempat kerja, tempat ibadah, dan pasar tradisional merupakan tempat publik yang berpotensi paling banyak dikunjungi. Acara dengan kerumunan besar, transportasi publik, serta wisata dan hiburan merupakan tempat dengan potensi kunjungan rendah. Tempat wisata dan hiburan, transportasi publik, dan pasar tradisional memiliki potensi penerapan prokes yang cukup rendah. Adapun acara hajatan/ritual sosial keagamaan, tempat ibadah, dan tempat kuliner memiliki potensi penerapan prokes yang baik.

Beberapa tempat dengan potensi kunjungan tinggi seperti tempat kerja, tempat ibadah, pasar tradisional, lingkungan tempat tinggal, dan tempat kuliner perlu diperhatikan penerapan prokesnya. Area publik yang perlu fasilitas olahraga publik lebih taat.

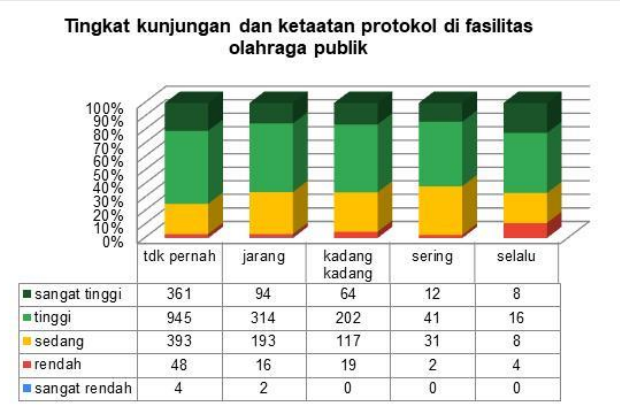

Gambar 13. Potensi kunjungan ke fasilitas olahraga publik dan pelaksanaan prokes

Penegakan prokes di tempat tempat kerja sangat penting dikarenakan tempat ini paling sering dikunjungi.

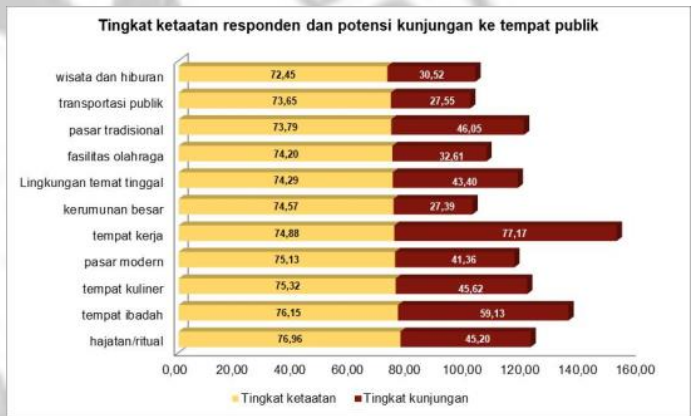

Gambar 15. Perbandingan tingkat pelaksanaan prokes dan potensi kunjngan ke tempat publik

dipertahankan dan ditingkatkan implementasi prokesnya adalah di pasar modern, tempat kuliner, tempat ibadah, serta acara hajatan dan ritual sosial keagaman atau pertemuan kecil, dimana potensi penerapan prokes cukup tinggi, serta potensi tingkat kunjungan cenderung cukup tinggi.

\section{UPAYA PENERAPAN PROTOKOL KESEHATAN (PROKES) DI RUANG PUBLIK}

Dalam penerapan prokes dari aspek individu, pemahaman responden terkait adaptasi kebiasaan baru secara umum sudah cukup baik. Sebagian besar memahami sebagai perubahan perilaku untuk tetap menjalankan aktivitas normal dengan menerapkan prokes.

Meskipun demikian, ada sebagian responden yang menyatakan mereka tidak tahu, atau menganggap berperilaku sebagaimana kondisi sebelum pandemi Covid-19. Mereka berasal dari kalangan pendidikan bawah, kelompok usia 60 tahun ke atas dan pekerjaan petani dan buruh. Pemberlakuan pola adaptasi kebiasaan 


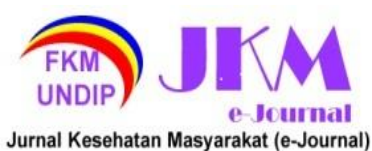

baru masih perlu edukasi lebih massif ke dalam kelompok tersebut.

Beberapa hal terkait pelaksanaan prokes yang masih rendah karena kurangnya edukasi, penegakan aturan, belum bisa membiasakan diri, dan keterbatasan sarpras. Edukasi dan penegakan regulasi untuk mendorong pihak-pihak tersebut mematuhi peraturan sangat diperlukan

Menurut berbagai penelitian, pengetahuan terhadap Covid 19 memiliki peran penting dalam rangka penanganan penyebaran Covid-19 (22). Penelitian Indriyanti menyimpulkan bahwa kesadaran diri yang rendah, akan beresiko mengabaikan beberapa prokes. ${ }^{(23)}$ Penelitian lain menemukan bahwa pengetahuan, sikap, tindakan, usia, tingkat pendidikan dan pendapatan merupakan faktor yang mempengaruhi perilaku masyarakat dalam pencegahan Covid-19 (24). Penelitian Prihati, Wirawati dan Supriyanti juga menemukan bahwa tingkat pengetahuan dan tingkat pendidikan berhubungan dengan perilaku pencegahan Covid-19. (25) Nilai yang dianut atau perspektif individu mempengaruhi pelaksanaan prokes, dan sebagian lagi dipengaruhi persuasi ${ }^{(26)}$. Sikap positif terhadap kebijakan penanganan Covid 19 akan memunculkan kepatuhan tinggi terhadap prokes covid $19^{(27) .}$

Beberapa penelitian lain, seperti Putra dan Manalu juga menemukan ada hubungan bermakna antara pengetahuan dengan perilaku masyarakat tentang Covid 19. (28) Tingkat pendidikan lebih tinggi (menengah-atas) dan pengetahuan lebih tinggi cenderung lebih patuh dibandingkan mereka dengan pendidikan lebih rendah dan pengetahuan yang rendah ${ }^{(29) \text {. }}$

Dengan demikian, pengetahuan (termasuk pendidikan) dan sikap sangat menentukan perilaku penerapan prokes. Sebagaimana hasil penelitian Sari dan 'Atiqoh bahwa kepatuhan masyarakat menggunakan masker sebagai upaya pencegahan Covid-19 memiliki hubungan dengan tingkat pengetahuan. (30) Hasil penelitian Riyadi dan Larasaty, menunjukkan bahwa responden yang menganggap wabah Covid-19 sebagai masalah serius akan memiliki tingkat kepatuhan yang lebih tinggi dalam penerapan prokes. (31) Penelitian lain menemukan bahwa untuk kalangan usia remaja, tingkat pengetahuan tidak berhubungan signifikan dengan kepatuhan menerapkan prokes (32). Hal tersebut dikarenakan mereka memiliki sikap mengabaikan, maka perlu motivasi dan dukungan berbagai pihak,

Oleh sebab itu, perlu peningkatan edukasi sehingga muncul kesadaran untuk menerapkan prokes terutama oleh pihak terkait (petugas kesehatan, satgas, dll), dibarengi dengan penegakan aturan prokes. Perlu edukasi dan pembelajaran untuk peningkatan pengetahuan masyarakat serta pentingnya peran petugas kesehatan dalam melakukan sosialisasi dan pemantauan di masyarakat (28). Demikian juga disampaikan oleh Prihati, K.Wirawati dan Supriyanti, bahwa peningkatan kesadaran masyarakat antara lain melalui sosialisasi dan pemantauan oleh petugas kesehatan sangat penting. (25) Penelitian di Kota Kediri, menunjukkan pengetahuan relawan Covid-19 tentang upaya pencegahan penularan Covid-19 yang kurang, akan menyebabkan kepatuhan relawan terhadap upaya pencegahan penularan Covid-19 juga kurang (33). Kerja sama antara pemerintah, tokoh masyarakat, dan tokoh agama juga sangat penting ${ }^{(34)}$. Selain melalui petugas kesehatan atau satgas Covid-19 dan tokoh masyarakat, edukasi juga bisa dilakukan melalui media sosial atau media elektronik lainnya. Penelitian di Kota Semarang menunjukkan 94,9 \% masyarakat menjadikan media sosial sebagai sumber informasi tentang covid-19, dan sebagian besar diantaranya (79\%) menggunakan media sosial untuk edukasi dan informasi, sisanya sebagai media komunikasi, early warning system serta sumber data ${ }^{(35)}$.

Hasil penelitian Lomboan, Rumayar dan Mandagi, bahwa penting untuk memberikan edukasi kepada masyarakat tentang Covid-19 karena sebagian masyaraakat belum paham betul, sehingga sebagian menjadi sangat panik, namun sebagian lagi kurang waspada (36) Pemberian informasi tentang Covid-19 dan prokes Covid-19 berdampak positif terhadap peningkatan pengetahuan masyarakat ${ }^{(32) \text {. }}$

Pada aspek implementasi prokes di tempat publik sangat dipengaruhi 2 hal, yaitu penegakan aturan dan ketersediaan sarana prasarana. Komitmen pengelola tempat publik dalam penegakan aturan prokes menjadi kunci utama implemetasi prokes. Selain itu, tempat publik juga harus disediakan sarana dan parsarana penerapan prokes. Penelitian terhadap pelaku UKM oleh Nismawati dan Marhtyni menemukan bahwa tidak hanya antara pengetahuan dan sikap, ketersediaan sarana dan prasarana juga sangat berhubungan dengan penerapan prokes pada pelaku usaha mikro. ${ }^{(37)}$

Berdasarkan data lapangan rata-rata tingkat penerapan prokes di area publik terbilang cukup tinggi, yaitu $74,67 \%$. Adapun potensi kunjungan ke temat publik masih tergolong sedang, yaitu $43,27 \%$. Beberapa tempat penting seperti tempat kerja, tempat ibadah, pasar tradisional, lingkungan tempat tinggal, dan tempat kuliner perlu lebih diperhatikan karena potensi kunjungan yang cukup tinggi. 


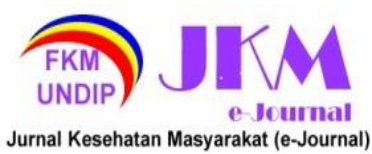

Penerapan prokes yang tertinggi bagi mereka yang sering atau selalu berkunjung ke area publik adalah pada lokasi hajatan atau ritual sosial keagaman, tempat ibadah, dan tempat kuliner, dan pasar modern. Jika dikaitkan dengan tingkat disiplin penerapan prokes, lokasi yang harus diwaspadai adalah tempat wisata dan hiburan, transportasi publik, dan pasar tradisional mengingat ada potensi peningkatan kunjungan yang cukup tinggi namun potensi penerapan belum cukup. Area yang perlu dipertahankan dan ditingkatkan adalah di pasar modern, tempat kuliner, tempat ibadah, serta acara hajatan dan ritual sosial keagaman atau pertemuan kecil, dimana potensi penerapan prokes cukup tinggi, serta tingkat kunjungan cenderung cukup tinggi.

Acara pertemuan yang menghadirkan kerumunan besar merupakan area publik tidak banyak dikunjungi responden. Tingkat kunjungan ini mungkin saja berubah di bulan-bulan kedepan sesuai dengan perkembangan situasi, pelonggaran dan kondisi perekonomian masyarakat. Pengadaan acara besar di luar ruangan masih harus dipertimbangkan, meskipun tingkat penerapan prokes berpotensi cukup baik, namun sulit melakukan pengendalian terhadap pengunjung. Oleh sebab itu pemberian ijin acara besar perlu mempertimbangkan berbagai aspek, mulai dari lokasi, pengunjung dan kesiapan penyelenggara.

\section{KESIMPULAN}

Sebagian besar menyadari bahwa pola adaptasi baru adalah perubahan perilaku dalam beraktifitas di ruang publik yaitu dengan penerapan prokes, namun ada yang menganggap sebagai kondisi normal seperti sebelum terjadi pandemi Covid-19, bahkan ada yang tidak mengetahui. Ketaatan responden dalam penerapan prokes sudah cukup baik terutama dalam mengenakan masker, dan mencuci tangan, atau menggunakan handsanitizer, namun upaya menjaga jarak dan menjauhi kerumunan masih perlu ditingkatkan. Penerapan prokes perlu didukung upaya edukasi serta penegakan aturan prokes secara tegas di ruang-ruang publik.

Area publik harus diwaspadai karena berpotensi menciptakan tingkat kerumunan cukup tinggi namun penerapan prokes belum optimal terutama tempat wisata dan hiburan, transportasi publik, dan pasar tradisional. Beberapa tempat dengan potensi kunjungan tinggi seperti tempat kerja, tempat ibadah, pasar tradisional, lingkungan tempat tinggal, dan tempat kuliner perlu diperhatikan penerapan prokesnya. Area publik yang perlu dipertahankan dan ditingkatkan implementas prokesnya adalah di pasar modern, tempat kuliner, tempat ibadah, serta acara hajatan dan ritual sosial keagaman atau pertemuan kecil, dimana potensi penerapan prokes cukup tinggi, serta tingkat kunjungan cenderung cukup tinggi.

\section{SARAN}

Tindakan utama yang perlu dilakukan adalah memastikan penerapan prokes secara baik terutama di ruang-ruang publik, agar berbagai kegiatan sosial ekonomi bisa dilaksanakan dalam batas tertentu. Peningkatan kesadaran masyarakat dalam penerapan prokes, terutama di ruang publik perlu menjadi perhatian. Pemerintah dan pihak terkait perlu meningkatkan edukasi melalui berbagai media, berbagai pendekatan sosial budaya dengan melibatkan unsur terkait seperti tokoh masyarakat, tokoh agama, dan perangkat pemerintahan terendah. Materi edukasi harus berisi pemahaman yang lengkap serta mudah dipahami.

Penegakan aturan di area publik sangat penting mengingat belum semua masyarakat memiliki kesadaran terhadap pentingnya pelaksanaan prokes. Pemerintah perlu menetapkan Standar Operasional Prosedur (SOP) yang ketat sebagai syarat pemberian ijin pembukaan area publik maupun acara-acara publik lainnya dan meningkatkan pengawasan terhadap pelaksanaan penerapan prokes di area publik.

Penelitian lanjutan masih diperlukan untuk mengidentifikasi faktor-faktor kunci implementasi prokes di ruang pubik. Tema lain yang masih perlu dikaji adalah bagaimana model adaptasi kebiasaan baru di masing-masing ruang publik untuk dapat dirumuskan menjadi SOP secara spesifik.

\section{DAFTAR PUSTAKA}

1. BPS Jawa Tengah. Hasil Survei Sosial Demografi Dampak Covid 19 Jawa Tengah 2020 [Internet]. 2020. Available from: https://jateng.bps.go.id/news/2020/06/03/3 79/hasil-survei-sosial-demografi-dampakcovid-19.html

2. Kuntardjo N, Sebong PH. Pola Interaksi dan Kepatuhan Protokol Kesehatan Oleh Pedagang di Pasar X Kota Semarang: Studi Kualitatif Eksploratif. VITASPHERE. 2020;1(1):1-10.

3. Rani N, Safarinda EY. Evaluasi Kebijakan Jogo Tonggo Dalam Penanganan Covid-19 di Provinsi Jawa Tengah. J Mhs Adm Negara. 2020;Jurnal Mah:8-15.

4. Sulistiani K, Kaslam K. Kebijakan Jogo Tonggo Pemerintah Provinsi Jawa Tengah dalam Penanganan Pandemi Covid-19. Vox Popul. 2020;3(1):31.

5. Alkomari. Analisi Komunikasi Krisis Gubernur Jawa Tengah Ganjar Pranowo 


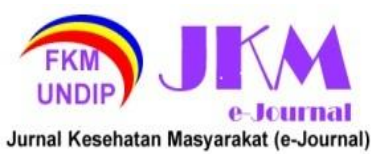

Menghadapi Pandemi Covid-19. Cover J Strateg Commun. 2020;Vol. 11, N:27-37.

6. Listyaningrum N, Philona R. Penegakan Hukum Protokol Kesehatan di Masa Pandemi. 2021;15(7):4727-40.

7. Buana DR. Analisis Perilaku Masyarakat Indonesia dalam Menghadapi Pandemi Virus Corona (Covid-19) dan Kiat Menjaga Kesejahteraan Jiwa. SALAM J Sos dan Budaya Syar-i. 2020;7(3).

8. Saidah D. Analisis Pelaksanaan Kebijakan Penangan Wabah Covid 19 di DKI Jakarta. J Ilm Adm Pemerintah Drh. 2020;12(2):20-30.

9. Saputro AA, Saputra YD, Prasetyo GB. Analisis Dampak Covid-19 Terhadap Kesadaran Masyarakat Dalam Penerapan Protokol Kesehatan. J Porkes. 2020;3(2):81-92.

10. Sagala SH, Maifita Y, Armaita. Hubungan Pengetahuan dan Sikap Masyarakat Terhadap Covid-19: A literature Review. J Menara Med https//jurnal.umsb.ac.id/index.php/menara medika/index JMM 2020 p-ISSN 2622657X, e-ISSN 2723-6862. 2020;3(1):4653.

11. Huljanah AM, Rahmawati N, Hidayah N, Prio A, Santoso A. Perilaku Masyarakat Dalam Penerapan Ketahanan Nasional Di Era Covid 19 Sebagai Bentuk Bela Negara. In: Seminar Nasional \& Call For Paper HUBISINTEK 2020. 2020. p. 37-43.

12. PH L, Suwoso RH, Febrianto T, Kushindarto D, Aziz F. Dampak Pandemi Covid-19 Bagi Perekonomian Masyarakat Desa. Indones J Nurs Heal Sci. 2020;1(1):37-48.

13. Sayuti RH, Hidayati SA. Dampak Pandemi Covid-19 Terhadap Ekonomi Masyarakat di Nusa Tenggara Barat. RESIPROKAL J Ris Sosiol Progresif Aktual. 2020;2(2):133-50.

14. Suryahadi A, Al Izzati R, Suryadarma D The Impact of COVID-19 Outbreak on Poverty: An Estimation for Indonesia (Draft). SMERU Work Pap [Internet]. 2020;April:1-20. Available from: http://smeru.or.id/en/content/impact-covid19-outbreak-poverty-estimation-indonesia

15. Yamali FR, Putri RN. Dampak Covid-19 Terhadap Ekonomi Indonesia. Ekon J Econ Bus. 2020;4(2):384.

16. Tasrif T. Dampak Covid 19 Terhadap Perubahan Struktur Sosial Budaya dan Ekonomi. EduSociata J Pendidik Sosiol [Internet]. 2020;III(2):88-109. Available from:

https://stkipbima.ac.id/jurnal/index.php/ES/ article/view/366

17. Yanuarita HA, Haryati S. Pengaruh Covid19 Terhadap Kondisi Sosial Budaya Di Kota Malang Dan Konsep Strategis Dalam Penanganannya. J Ilm Widya Sosiopolitika. 2021;2(2):58

18. Ngadi N, Meliana R, Purba YA. Dampak Pandemi Covid-19 Terhadap Phk Dan Pendapatan Pekerja Di Indonesia. J Kependud Indones. 2020;2902:43.

19. Azimah RN, Khasanah IN, Pratama R, Azizah Z, Febriantoro W, Purnomo SRS. Analisis Dampak Covid-19 Terhadap Sosial Ekonomi Pedagang Di Pasar Klaten Dan Wonogiri. EMPATI J Ilmu Kesejaht Sos. 2020;9(1):59-68.

20. Sukamerta IM. Peran Desa Adat Dalam Penanganan COVID-19 di Indonesia. In: Proceedings Nasional Universitas Mahasaraswati Denpasar. 2020. p. 1-4.

21. BPS Jawa Tengah. Provinsi Jawa Tengah Dalam Angka 2021 [Internet]. Semarang; 2021. Available from: https://jateng.bps.go.id/publication/2021/02 /26/c5709cd0419788a55827d58f/provinsijawa-tengah-dalam-angka-2021.html

22. Yanti NPED, Nugraha IMADP, Wisnawa GA, Agustina NPD, Diantari NPA. Public Knowledge about Covid-19 and Public Behavior During the Covid-19 Pandemic. J Keperawatan Jiwa. 2020;8(4):491.

23. Indriyanti D, Cikarang B, Raya J, No L, Utara C, Barat J. Implementasi Protokol Kesehatan Pada Petugas Puskesmas Di Masa Pandemi : Studi Kasus Puskesmas Cileungsi Kabupaten Bogor Implementation of Health Protocols in Puskesmas Offices in Pandemic: Case Study of Puskesmas Cileungsi Bogor District. Inov Apar. 2020;2(2):235-46.

24. Wonok MJ, Wowor R, Tucunan AAT. Gambaran Perilaku Masyarakat Tentang Pencegahan Covid-19 Di Desa Tumani Kecamatan Maesan Kabupaten Minahasa Selatan. J KESMAS. 2020;9(7):147-56.

25. Prihati DR, K.Wirawati M, Supriyanti E. Analisis Pengetahuan Dan Perilaku Masyarakat Di Kelurahan Baru Kotawaringin Barat Tentang Covid 19. 2020;2(September):780-90.

26. Kasim SIA, Awalyah M, Nurkhalifa N. Pengaruh Persuasi Protokol Kesehatan Terhadap Di Era Adaptasi Kebiasaan Baru. J ABDI. 2021;3(1).

27. Afrianti N, Rahmiati C. Faktor-Faktor 
Yang Mempengaruhi Kepatuhan http://ejournal3.undip.ac.id/index.php/jkm

Masyarakat Terhadap Protokol Kesehatan Covid-19. J Ilm STIKES Kendal. 2021;11(1):113-24.

28. Putra YIW, Manalu NV. Tingkat Pengetahuan Dengan Perilaku Warga Dalam Menjalankan Protokol Kesehatan di Masa New Normal Pandemi Corona. Community Publ Nurs. 2020;8(4):366-73.

29. Wiranti, Sriatmi A, Kusumastuti W. Determinan kepatuhan masyarakat kota depok terhadap kebijakan pembatasan sosial berskala besar dalam pencegahan covid-19. 2020;09(03):117-24.

30. Sari DP, 'Atiqoh NS. Hubungan Antara Pengetahuan Masyarakat Dengan Kepatuhan Penggunaan Masker Sebagai Upaya Pencegahan Penyakit Covid-19 Di Ngronggah. Infokes J Ilm Rekam Medis dan Inform Kesehat. 2020;10(1):52-5.

31. Riyadi, Larasaty P. Faktor Yang Berpengaruh Terhadap Kepatuhan Masyarakat Pada Protokol Kesehatan Dalam Mencegah Penyebaran COVID-19. In: Seminar Nasional Official Statistics 2020: Pemodelan Statistika tentang Covid19. 2020. p. 45-54.

32. Sari AR, Fauzie Rahman, Wulandari A, Pujianti N, Laily N, Anhar VY, et al. Perilaku Pencegahan Covid-19 Ditinjau dari Karakteristik Individu dan Sikap Masyarakat. J Chem Inf Model. 2020;53(9):1689-99.

33. R EQ, Alimansur M. persetujuan etik dari komisi etik penelitian kesehatan Akper Dharma Husada Kediri No. 2020;4(1):817.

34. Syafrida S, Hartati R. Bersama Melawan Virus Covid 19 di Indonesia. SALAM J Sos dan Budaya Syar-i. 2020;7(6):495508.

35. Findayani A. Peran Sosial Media dalam Penyampaian Informasi dan Kesiapsiagaan Masyarakat Menghadapi Covid-19 di Kota Semarang. J Geogr Media Inf Pengemb dan Profesi Kegeografian. 2020;17(2):639.

36. Lomboan M V., Rumayar AA, Mandagi CKF. Gambaran Persepsi Masyarakat Tentang Pencegahan Covid-19 Di Kelurahan Talikuran Utara Kecamatan Kawangkoan Utara. J KESMAS. 2020;9(4):111-7.

37. Nismawati N, Marhtyni M. Faktor Yang Berhubungan Dengan Penerapan Protokol Kesehatan Pada Pelaku Usaha Mikro Selama masa Pandemi Covid -19. UNM 